\title{
KERKVERBAND TOT OOR DIE NASIONALE GRENSE
}

\section{Onafhanklike kerke?}

Die vraag oor die verhouding tussen die sg. ou en jong kerke het veral sedert 1945 baic aktueel in die Protestantse Sending geword, want terwyl sedert ongeveer 1850 as sendingdoel gestel is die ontwikkeling van selfstandige kerke, het baie van hierdie jong kerke veral vanweë die onafhanklikwording van die betrokke nie-blanke lande selfstandig geword, hoewel die destyds gangbare beskouing van die Protestantse sending was dat hulle eintlik nog nie daarvoor ryp was nie.

Sedertdien is byna algemeen tot die Skrifbeskouing teruggekeer dat 'n gemeente van Christus selfstandig is sodra dit gestig is, maar die verhoudingsvraagstuk is tot dusver nog nie opgelos nie. Die "ou" en ,,jong" kerke is in die reël onafhanklik van mekaar en sonder kerklike verband met mekaar.

Ons wil by die lig van die Skrif probeer nagaan of ' $n$ mens wel van mekaar as onafhanklike kerke kan spreek en hoe die verband moet wees.

\section{Die eenheid, universaliteit en verskeidenheid van die kerk}

Om dit te doen wil ons uitgaan van die universaliteit, die eenheid en die verskeidenheid van die kerk van Christus, en probeer aantoon wat dit vir ons onderwerp inhou.

Omdat die kerk in sy volheid (pleroma) die nuwe, die ware mensheid is waarin die beeld van God gesien word en die Drieënige God self ' $n$ velbondsdrieëenheid is in die verskeidenheid en eenheid van die dric Persone, en God die universele Here is van die hele wêreld en die hele mensheid, is daar eenheid, universaliteit en verskeidenheid in die kerk van die Here.

Daarom is die skepping van die mens as beeld van God ook daarop gerig om die een mensheid van God in sy universaliteit verskeidenheid en eenheid te openbaar en te verwesenlik. Indien die sondeval nie ingetree het nie, sou die een mensheid in sy verskeidenheid en universaliteit in 'n organiese geheel van volke oor die hele wêreld versprei het, maar met die sondeval is dit 'n eskatologiese werklikheid wat eers met die voleinding ten volle gerealiseer sal word.

Om dit ten uitvoer te bring is die Drieëenheid onderling 
aan mekaar verbind en tree al drie die Persone in die geskiedenis op: God die Vader in die eerste plek in die skepping en voorsienigheid, die Here wat alles in die geskiedenis tot die bestemde doel lei; die Seun wat gestuur word om die mensheid te verlos, en die Heilige Gees om die volk van God tot aan die voleinding te bewaar, om aan die volk die nuwe lewe te skenk en dit te bring tot dic volheid van die bestemming van die mensheid.

Dit dan wat betref die Trinitariese fundering, maar daar is ook die Christologiese functering, want wat eers met die voleinding ten volle verwesenlik sal word, is reeds in beginsel deur Christus tot stand gebring, sodat daar in Hom reeds die een nuwe mensheid is, die mensheid in sy eenheid, sy universaliteit en sy verskeidenheid. Van hierdie werklikheid moet daar reeds nou 'n weerspieëling gesien word in die kerk van die Here op aarde.

Daar is ten slotte ook nog die cskatalogiese fundering die eskatalogiese volheidsbestemming van die mensheid moet reeds nou in 'n sekere mate in die volk van die Here gesien word, in al die verhoudinge en terreine waarin die gelowiges te staan kom. Die kerk moet op weg wees na die volheid, dit moet daarheen groei en beweeg.

Uit die mensheid word die volk van God uit alle volke geroep om in Christus 'n voorlopige realisering van die alles tc openbaar. Al kan al die volke nie in een en dieselfde institutêre kerkverband verteenwoordig wees nie, moet daar tog in beginsel iets daarvan gesien en weerspieël word.

Dit dan baie kortliks wat betref die Trinitaries, Christologiese en eskatalogiese fundering van hierdie drievoudigheid van eenheid, universaliteit en verskeidenheid. Ons wil nou verder oor elkeen van die drie aspekte afsonderlik handel.

\section{Die eenheid van die kerk}

In die eerste plek moet voorop staan dat die eenheid van die kerk van die Here reeds 'n werklikheid in Christus is. Dit is dus nie iets wat nog gefabriseer moet word nie. Dit is die eenheid van die nuwe mensheid in Christus. Hoewel die realisering van daardie eenheid in die volk van die Here ook moet groei tot die volheid (pleroma) van die bestemming wat God vir sy volk in die vooruitsig stel (Ef. $1: 2,3 ; 3: 19$, Kol. 2 : 9) en Christus bid dat sy volk een mag wees (Joh. 
$17: 21$, moet die werklike, die eintlike eenheid nie nog verwesenlik word nie en kan dit nie deur menslike toedoen bewerk word nie, want dit is reeds 'n werklikheid in Christus. Om dit te bewerk het Christus versoening vir die sondes gedoen en is $\mathrm{Hy}$ die Hoof van sy gemeente wat sy liggaam (Ef. $5: 22-23$ ) is; sy gemeente is 'n gebou, 'n geestelike tempel waarvan Christus die hoeksteen is (Ef. 2 : 20); Hy is die wynstok en die gelowiges die lote (Joh. $15: 5$ ).

Omdat die eenheid 'n werklikheid in Christus is, moet daar ook nou iets daarvan in die kerklike instituut aan die lig tree, in die eerste plek in die plaaslike gemeente. Eenheid word egter nie bewerk deurdat die lidmate van dieselfde plek tot die stigting van 'n gemeente oorgaan nie, maar omdat die gelowiges lidmate is van die een liggaam van Christus moet daar ook 'n openbaring van die een liggaam in die plaaslike gemeente wees, moet die lidmate in 'n nadere verband met mekaar in dieselfde plaaslike gemeente tree.

Hierin het die lidmate nie 'n keuse nie, maar vanweë die eenheid in Christus en vanweë hulle roeping as gelowiges is hulle verplig om oor te gaan tot kerkinstitutering. Kuyper stel die menslike faktor te veel op die voorgrond met sy bewering dat daar vir dergelike instituering die wilsdaad van die gelowiges tot aaneensluiting nodig is (Tractaat van de Reformatie, Amsterdam, 1884, p. 29).

Kerkverband hou egter nie by die plaaslike gemeente op nie, maar omdat die verskillende plaaslike gemeentes van die verskillende plekke openbaringe is van dieselfde liggaam, van die een universele kerk wat reeds in Christus 'n werklikheid is, is daar ook ' $n$ wyere kerkverband as net in die plaaslike gemeentes. Maar ook in hierdie geval word daar nie 'n eenheid bewerk deur die saamsnoering van die verskillende gemeentes nie. Die eenheid is reeds daar en iets daarvan moet nou in die kerkverband gesien word: „Niet eerst door het leggen van dezen band komen ze (die gemeentes) bijeen te hooren, maar omdat zij bijeen hooren, moet ook deze band uitwendig worden aangelegd" (A. Kuyper: Dictaat, Dogmatiek, Kampen, De Ecclesia, p. 259).

Die Skriftuurlike kerkbegrip kom nie daarop neer dat die dele (die gemeentes) in die geheel opgaan nie (Rooms-Katolisisme), ook nie dat die geheel in die dele opgaan nie (Independentisme) en ook nie dat die geheel uit die dele saamgestel word nie (Kollegialisme). Ons kry, soos W. J. Snyman sê, nie 
'n inmekaar of teenmekaar of naasmekaar nie, maar 'n namekaar (Koers, Feb. 1949, p. 123): die algemene kerk gaan aan die plaaslike vooraf. Volgens Herman Ridderbos vloei as vanself uit die Nieu-Testamentiese kerkbegrip voort dat nie die samevoeging of optelling van die afsonderlike gemeentes die kerk as geheel tot stand bring nie, maar dat in elke plaaslike kerk, al is dit nog so klein, die kerk as geheel hom openbaar. Die kerk is 'n organiese grootheid waarvan die geheel aan die dele, die eenheid aan die veelheid voorafgaan. „Enerzijds wordt hierdoor de gedachte uitgesloten als zou de plaatselijke gemeente slechts een onderafdeling in haar geheel zijn... Het is veelmeer het ene lichaam van Christus, het ene volk Gods, dat in de plaatselijke gemeente leeft en zich openbaart en haar binnen dit ene lichaam haar zelfstandigheid en vrijheid geeft. Anderzijds vormen niet de plaatselijke gemeenten de constituerende delen van de kerk, die daardoor slechts een federatief karakter zou dragen welker eenheids-openbaring slechts van secundaire en conditionele betekenis zou zijn" ( $N$. H. Ridderbos in De Apostolische Kerk, Kampen, 1954, p. 94).

Ook dr. H. Bavinck verskil nie van hierdie opvatting nie: „de ecclesia catholica is er eerst, zij heeft haar bestand in Christus, kwam in de dagen des N.T. het eerste tot openbaring in de kerk te Jeruzalem en breidde zich van daar in andere plaatsen uit. Elke ecclesia particularis (localis) is daar ter plaatse, waar zij optreedt, eene openbaring van de ecclesia catholica, van het volk Gods ... De ecclesiae particulares ... zijn plaatselijke openbaringen van het eene mystieke lichaam van Christus, zijn daarom geestelijk een, staan krachtens haar historische oorsprong met elkander in verband en zijn tot het onderhouden der gemeenschap met allen, die hetzelfde geloof deelachtig zijn, van 's Heeren wege verplicht. Elke plaatselijke kerk is daarom tegelijkertijd een zelfstandige openbaring van het lichaam van Christus en een deel van een groter geheel" (H. Bavinck: Dogmatiek, IV, Kampen, 1911, p. 407-9).

„Wijl de gemeente een organisme is, gaat het hoofd aan de leden en die ecclesia universalis aan die ecclesia particularis vooraf (H. Bavinck, a.w., p. 407).

"Elke gemeente is een zelfstandige openbaring van het lichaam van Christus en een deel van een grooter geheel" dit kom dus daarop neer dat hoewel 'n gemeente selfstandig is, dit nooit onafhanklik van ander gemeentes is nie. Omdat 
al die gemeentes op gelyke wyse aan Christus verbind is en almal openbarings is van dieselfde liggaam van Christus (Ef. $5: 13$ ), is al die gemeentes in kerkverband met mekaar.

Uit bostaande volg verder dat die kerk van Christus nie uiteenval en opgebreek mag word in verskillende van mekaar onafhanklike lands- of provinsiale kerke nie, elkeen met sy eie sinode wat dan weer saam in een algemene sinode wat bo oor al die ander sinodes staan, opgeneem word om op hierdie manier ' $n$ eenheid te vorm nie. Dan kry ons verskillende afsonderiike "kerke" elkeen met sy eie sinode. Nou moet hierdie kerke 'n eenheid word deur die saambinding in een algemene sinode. Die dele word saamgevoeg om 'n geheeleenheid te vorm. Dit is heeltemal teenstrydig met die Skriftuurlike kerkbegrip. Dit is deur en deur kollegialisme. Dit kom daarop neer dat in die sinode die eintlike kerk gesien word en die verskillende kerke verenig nou tot een kerk in een algemene sinode waarvan die verskillende kerke vertakkinge is.

Die Skrif ken egter nie 'n lands-, volks- of provinsiale kerk nie. Die Skrif gebruik die woord kerk (ekklesia) net vir die plaaslike gemeente en die universele kerk. Hoewel verskillende gemeentes van een landstreek soms saamgegroepeer word, word daar nooit in die Skrif van 'n landskerk gespreek nie. Paulus spreek bv. nie van die kerk van Galasië of die kerk van Judea of van Asië ens. nie, maar van die kerke (gemeentes) van Galasië (1 Kor. $16: 1$, Gal. 1 : 22), van Asië (1 Kor. $16: 19$ ), van Judea (Gal. $1: 22$ ).

Die verskillende gemeentes was in die apostoliese tyd wel nie verbind in 'n institutêre verband nie, maar daar was wel 'n hegte eenheidsband tussen die verskillende gemeentes. Hierdie eenheid is op baie maniere geopenbaar. In die apostels wat die leiding in die gemeente gehad het en wie se leer die fondament van die kerk geword het, was al die gemeentes een. Hulle was die grondleggers van die kerk en het in hulle persone die universele kerk verteenwoordig. Paulus het die band met die gemeentes bewaar, hulle gereeld besoek, met hulle gekorrespondeer, briewe tot hulle gerig wat in die eredienste voorgelees moes word, hy bring die groete van die verskillende gemeentes an mekaar oor. Die een gemeento dra vir sy onderhoud by, terwyl hy in 'n ander een arbej. Die gemeentes uit die heidene hou 'n kollekte vir die armes van Jerusalem ens. Daar was eenheid van belydenis, almal was saamverbind in dieselfde evangelie. Daar was 'n lewendige 
besef dat al die gelowiges lede is van die een volk van God. Hoewel daar nie 'n institutêre kerkverband was nie, was die kerk tog 'n instituut vanweë die band in die apostels on die afgrensing na buite deur die doop. Daarbenewens het die geestelike gemeenskap tussen die verskillende gemeentes, soos $\mathrm{dr}$. H. Bavinck sê, die eenheid heerliker en mooier as die beste reglement geopenbaar. (H. Bavinck: De Katholiciteit van Christendom en kerk, Kampen, 1888).

Die bewaring van die eenheid was onder destydse omstandighede 'n mocilike saak en dit is veral bemoeilik deur die Judaïstiese rigting in en buite die kerk. Daar was diep gewortelde verskille tussen die verskillende etniese groepe. En tog was daar ' $n$ heerlike eenheid. Die gemeentes van die eerste eeu was verskillend in herkoms, in woonplek, in beskawing, nasionaliteit, 'n eeueoue verlede, 'n heeltemal ander geskiedenis, verskillende kultuur, 'n muur van afskeiding, 'n diep gewortelde vyandskap. In die kerk was daar Samaritane, die aartsvyande van die Jode wat hulle baie diep verag het, daar was die onbesnede Grieke en Romeine, Jode wat met die wet van Moses groot geword het en wat Israel as die uitverkore en eintlike volk van God beskou het waarin die heidene opgeneem moes word om lede van die volk van God te word. Ons kan ons moeilik voorstel hoe moeilik, hoe menslik onmoontlik dit was om onder die destydse omstandighede eenheid te handhaaf.

Ten spyte van al hierdie verskille en verskeidenhede en botsende belange het Paulus of die lidmate nooit daaraan gedink om aparte kerke te stig nie. Altyd is die kerk as 'n eenheid gesien, die liggaam van Christus: „Dit is een geloof, een doop, een God en Vader" (Ef. 4 : 4-6). Daar is net die een kerk van die Here en hierdie een kerk kan onmoontlik in twee of meer kerk opgebreek word nie.

Vir Paulus was hierdie eenheid ' $n$ uiters noodsaaklike en altyd dringende aangeleentheid. Dit was vir hom 'n lewensaak. Dit was 'n eenheid wat veral op die eenheid van die belydenis gebaseer moet wees en daarin tot openbaring moet kom. Almal moet in dieselfde evangelie aan mekaar verbind wees: vervloek is elkeen wat ' $n$ ander evangelie as myne bring, sê Paulus (Gal. 1:8). Omdat die eenheid 'n werklikheid in Christus is, het dit ook in die kerk tot uiting gekom. Dit was 'n werklikheid waarvoor Paulus God telkens loof en dank: dit is ' $n$ groot misterie dat nl. Jood en nie-Jood nie alleen in en 
deur Christus met mekaar versoen is nie, maar dat hulle saam lede is van die een liggaam van Christus (Ef. 2 : 16), dat hulle saam in die een gebou (die kerk) ingebou word (Ef. 2 : 19-21) en satam opgebou word tot 'n woning van God (Ef. 2 : 22). Hicrdie misterie was al die eeue verborge, sê Paulus, maar is nou geopenbaar (Ef. 3 : 1-6).

Hoe skerp steek die huidige versplintering van die kerk in baie kerke nic af by die eenheid van die Nieu-Testamentiese kerk. Die ideaal sou wees dat daar op elke plek net een plaaslike gemeent: moet wees en dat al die plaaslike gemeentes in een kerkverband verbind word. Dit kan egter nie gebeur nie, want 'n unmisbare vereiste is die eenheid in belydenis. Daar kan alleen sprake wees van kerkverband van gemeentes wat een is in die belydenis, want die kerk van die Here word gebou op die belydenis van die apostels en profete (Ef. 2 : 20); omdat dit so is, moet die verskillende gemeentes van dieselfde belydenis ook in kerkverband wees, om op hierdie wyse iets te laat sien van die eenheid van die universele kerk van Christus. Daarop moet die lewe en denke van die gelowiges gerig wees, so moet hulle die universele eenheid beleef en ervaar en gestalte laat kry.

In hierdie verband is die eenheidsband van die gemeentes onder die nie-blankes met dié onder die blankes van baie groot betekenis veral vir eersgenoemdes, want in die geval van sulke jong, onervare en minder goed ingeligte gemeentes is die gevaar nie uitgesluit dat hulle vanweë onkunde of ander oorsake prinsipieel van die waarheid kan afwyk en selfs kan uiteenskeur in verskillende aparte kerke nie. Vanweë die eenheid in Christus, wat ook insluit dat die gemeentes saam opgebou word tot die woning van God (Ef. $2: 22$ ), saam in die cen kerk ingebou word (Ef. 2 : 19-21) en saam moet groei tot die eenheid van die geloof en die kennis van die Seun van God (Ef. 4 : 13), moet die gemeentes op mekaar toesien, moet hulle saamgebind word deur dieselfde belydenis, saam optree in gemeenskaplike belange, saam besluit oor die nodige wysiginge of byvoeginge in die belydenis ens. Daarom is die kerkverband tussen blanke en nie-blanke gemeentes só belangrik.

Maar dit is nie die eintlike motief vir die kerkverband nie. Dit is nie daarom dat tot die instituering van 'n kerkverband oorgegaan moet word nie, want daar word eenvoudig nie tot 'n kerkverband oorgegaan nie. Sodra 'n gemeente 
onder die nie-blankes of blankes gestig word is dit reeds in kerkverband. Hierdie kerkverband moet dan net nader gereël word. 'n Gemeente onder die nie-blankes is kragtens die eenheid in Christus, kragtens die historiese ontstaan van die gemeente en kragtens die eenheid in belydenis reeds in kerkverband met ander gemeentes van dieselfde belydenis. Die kerkverband moet dan net nader gereël word.

Die gemeentes wat een is in belydenis - en hieronder verstaan ons 'n fundamentele eenheid in belydenis, kerkregering en erediens - mcet dus ook in nadere institutêre verband tree. Die eenheid wat daar in Christus is moet ook in die institutêre verband tot openbaring kom. Gemeentes wat bv. as gevolg van die sendingwerk van die Gereformeerde Kerk gestig is, is vanselfsprekend Gereformeerde gemeentes en daarom moet die institutêre verband tussen hulle ook gereël en in werking gestel word.

\section{Die universaliteit van die kerk}

Op die vraag wat verstaan moet word onder die heilige algemene (katolieke) kerk, antwoord die Heidelbergse Kategismus in Sondag 21 dat die „Seun van God uit die ganse menslike geslag vir Hom 'n gemeente, wat tot die ewige lewe verkies is deur sy Gees en Woord in die eenheid van die ware geloof van die begin van die wêreld af tot aan die einde toe vergader, beskerm en onderhou", en die Nederlandse Geloofsbelydenis verklaar in art. 27 dat ,hierdie heilige kerk nie gelë is in, gebonde aan of bepaal tot sekere plekke of tot sekere persone nie, maar dit is verspreid en verstrooid oor die hele wêreld".

In sy rektorale rede in 1888 oor De Katholiciteit van Christendom en kerk, gebruik dr. H. Bavinck die woord katoliek ook nog in 'n tweede betekenis, nl. in die kwalitatiewe betekenis van die heiliging van die hele aardse werklikheid. Die katolisiteit van die kerk kom daarin aan die lig dat nie alleen geen enkele land buite die evangelie moet bly nie, maar ook dat geen enkele lewenstruktuur (gesin, staat, sosiale verhoudinge ens.) aan die beslag van die Woord van God onttrek kan word nie (p. 44 e.v.). Dit het dus ook betrekking op wat in die Gereformeerde teologie die kerk as organisme genoem word. God moet soewerein wees op alle lewensterreine. (Dr. H. Berkhof gebruik in sy De Katholiciteit der kerk die 
woord ook in hierdie tweevoudige betekenis, ook Herman Ridderbos in De Apostolische kerk, p. 71-72).

Om die twee betekenisse saam te vat wil ons egter liewer spreek van die universaliteit van die kerk van Christus. Die kerk is universee!, want Christus is die Verlosser van die hele wêreld ( 2 Kor. 5 : 15; Joh. $3: 16 ; 4: 14$ ens.); in Christus is alle dinge in die hemel en op die aarde met God versoen (Kol. $1: 20$ ) en onder Hom word alles tot een vergader (Ef. 1 : 12); God het Christus as Hoof bo alle dinge aan die gemeente gegee wat sy liggaam is, die volheid van Hom wat alles in almal vervul (Ef. 1:23); daar kom 'n nuwe hemel en aarde waarin geregtigheid woon (2 Petrus 3 : 13); Christus is die Verlosser van die nuwe mensheid waarvan $\mathrm{Hy}$ as tweede Adam die Hoof is (Rom. 6:12-21); dit is die nuwe mensheid uit al die volke; alle volke gaan na Jerusalem om daar die wet van die Here te leer (Jes. $2: 2$ ), en die Here van die leërskare sal op hierdie berg (Sinaï) vir al die volke 'n maaltyd berei (Jes. $25: 61$ ).

Dit is 'n universaliteit wat alle volke omvat en betrekking het op die hele lewe en al die lewensterreine. Om dit gestalte te laat aanneem het Christus alle mag in hemel en op aarde ontvang en daarom dra $\mathrm{Hy}$ aan sy kerk op om dissipels van alle nasies te mak, asook om hulle te leer om alles te onderhou wat Hy sy dissipels beveel het (Matth. 28 : 18-19). Hierdie opdrag het nie alleen betrekking op die uitbreiding van die kerk onder al die volke nie, maar ook op die openbaring en die werklikheid van die koninkryk van God en die koningskap van Christus as Pantokrator op alle terreine van die lewe, want op al die lewensterreine en onder alle volke moet van toepassing gemaak word alles wat Christus geleer het en in al hierdie betrekkinge moet die volheid van Christus in die lewe van die gelowiges onder alle volke geopenbaar word (vgl. Ef. 4-6:1).

Geen volk of ras mag dus oorgeslaan word nie: onder alle volke moet die werklikheid van die koninkryk van God geopenbaar word en moet daar 'n weerspieëling wees van die komende koninkryk in heerlikheid. Dit moet gebeur deur die verkondiging van die Woord van God, die onderrig en deur die planting van gemeentes, en iets daarvan moet gesien word in die lewe van die gelowiges in die hele lewe en op alle lewensterreine. 
Van volk tot volk moet die Woord van God aan alle nasies verkondig word, van Jerusalem af en verder in Judea en daarvandaan verder in Samaria en tot aan die eindes van die aarde (Luk. $24: 47$, Hand. $1: 8$ ). Dit is 'n allesomvattende opdrag wat aanhou tot aan die voleinding; eers wanneer hierdie taak volbring is, sal die einde daar wees (Matth. $24: 14$, Mark. 13 : 10), maar die kerk moet nie net geografies uitbrei tot aan die einde van die aarde nie en kwantitatief groei tot die volheid van die liggaam van Christus, totdat al die stene in die gebou ingevoeg is nie (Ef. 2), maar dit moet ook kwalitatief groei, ,totdat ons almal kom tot die eenheid van geloof en van die kennis van die Seun van God" (Ef. $4: 13$ ), d.w.s. al die gelowiges moet groei tot die eenheid waarin almal in alles en in die hele lewe in niks toegee aan die sonde, die leuen en die valse leer nie, maar in alles buig vir die Woord van die Koning van die koninkryk en die Hoof van die kerk. Ons moet ons steeds minder laat voorsê deur die wêreldmagte en winde van leer om ons geheel en al oor te gee aan die belofte en leiding van ons Hoof (vgl. H. Berkhof: De Katholiciteit der kerk, p. 84).

Uit bostaande volg dus in die eerste plek dat die kerk as instituut en organisme onder alle volke geopenbaar moet word, in die tweede plek dat hierin daar reeds nou iets gesien moet word van 'n openbaring van die werklikheid van die koninkryk van God en 'n weerspieëling van die eskatologiese volheid en heerlikheid van die koninkryk van God, asook van die uiteindelike bestemming van die mens en die volke, wanneer die eer en heerlikheid van die volke in die nuwe Jerusalem ingebring sal word (Openb. 21 : 26). Die aanvanklike realisering van die koninkryk asook die uiteindelike bestemming van die mens, die volke, die mensheid - daarvan moet dus nou reeds iets geopenbaar word onder alle volke. Daarvoor het Christus alle mag ontvang en laat $\mathrm{Hy}$ ons saamgroei en saamwerk tot die eenheid van die geloof en van die kennis van die Seun van God (Ef. $4: 13$ ), tot die opgroeiing in Hom wat die Hoof is, nl. Christus (vs. 15), tot die opbouing van die liggaam van Christus (vs. 12) wat alles tot volheid bring (vs. 10).

Daarom kan die kerkverband nie by die nasionale grense ophou nie; omdat die kerk ekumenies is, moet die kerkverband ook ekumenies wees. Die verpligting tot korrespondensie tussen die gemeentes of "konfederasie" van die gemeente vloei 
volgens dr. Kuyper voort uit die aard van „het kerkelijk wezen". Hierdie eis bly volgens hom onder alle omstandighede staan, selfs waar so 'n samelewing nog nie moontlik is nie: „Juist daarom mag deze eisch niet beperkt worden tot de kerken van één zelfde land, maar gaat door voor alle kerken op aarde, en het ideaal zou eerst dan bereikt zijn, indien alle kerken op aarde in ééne confederatie saamleefden, in één concilie de kerkelijke macht konden saambrengen; en in één zelfde confessie zich konden uitspreken" (Locus de Ecclesin, p. 252-253).

Dr. Bouwman laat hom as volg hieroor uit: „Een Generale Synode waarheen de kerken van eene belijdenis - waar ter wereld ook -- hare afgevaardigden hadden gezonden, is het ideaal van de Gereformeerde kerken geweest. Zij beschouwden de kerk niet beperkt tot één volk, maar zij hebben steeds bedoeld de zuiverste en edelste openbaring van de bruid Christi op aarde te wezen... Uit kracht van deze belijdenis konden de Gereformeerden niet anders dan trachten overal de beginselen, die zij de ware achten, te verbreiden, en de eenheid te zoeken van al de Gereformeerde belijders... In 1536 is er, volgens de Corte Memoriën, sprake geweest van de bijeenroeping van eene Synode Oecumenica, maar zij kwam niet tot stand" (H. Bouwman: Geref. Kerkrecht II, Kampen, 1928, p. 197).

Ook dr. K. Dijk laat hicroor geen onsekere geluid hoor nie: „Hier moge alleen opgemerkt worden dat de eis der Schrift en de nood der tijden" ons dwingen om de toenadering te zoeken in de enigheid van het ware geloof: een eenheid die geen vrede kan hebben met de moderne oecumenisiteit, maar allereerst begeerd moet worden in samenbinding van de gereformeerde gezindte, eerst in ons vaderland, en dan ook daarbuiten, in geheel de wereld, de apostoliciteit moet met deze cathalociteit gepaard gaan" (K. Dijk: De Apostolische kerk, Kampen, 1954, p. 174).

Ook die Algemene Sinode van die Gereformeerde Kerk in S.A. het besluit dat dit wenslik is dat daar ' $n$ ekumeniese verband van Geref. Kerke moet wees. In 1955 het die sinode $\mathrm{nl}$. op die vraag of die kerkverband verder strek as die nasionale en of territoriale grense bevestigend geantwoord: "Gereformeerde Kerke in verskillende lande wat een is in belydenis en kerkregering (Ned. Gel. Bel., art. 29) kan saamkom as 'n gewone ekumeniese sinode na analogie van art. 30 K.O." Weens 
praktiese besware besluit die sinode egter om te volstaan met die huidige Geref. Ekumeniese Sinode. Hierdie vergadering is egter nie in die volle betekenis van die woord 'n sinode nie en die ledekcrke is ook nie almal een in leer, diens en tug nie. Die besluit van die sinode kom, wat betref die kerkverband tussen die Geref. kerke onder verskillende volke, dus daarop neer dat berus word in wat dr. A. Kuyper noem die swakkere vorm van kerkverband, $\mathrm{nl}$. die van korrespondensie (Kuyper, a.w., p. 253).

Sodanige korrespondensie is ook nodig en ook belangrik, maar dan moet dit, veral waar ons soos in Suid-Afrika verskillende volke binne dieselfde landsgrense het, verder uitgebrei word en nouer wees as wat gewoonlik deur korrespondensie onderhou word. Deputate van gemeente tot gemeente en meerdere vergadering tot meerdere vergadering moet gereeld gesamentlik vergader oor sake van gemeenskaplike belang en wanneer advies en leiding nodig is.

Dit asook 'n Algemene Sinode waarop meerdere vergaderings onder verskillende volke in een Algemene Sinode vergader, is geen nuwe beginscl in die Gereformeerde Kerk nie, want dit is al in die 16e eeu in Nederland toegepas. In hierdie geval het ons aparte Waalssprekende gemeentes gehad met hulle eie meerdere vergaderings tot op 'n Partikulierc Sinode, maar al die gemeentes was weer saam verbind in een Generale Sinode (Kerkorde van Dordrecht, 1618-1619, art. 51 en Kerkorde, Dordrecht 1578, art. 31).

Ook insake die nouere vorm van korrespondensie dui die Kerkorde van Dordrecht (1618-1619) die weg aan deur die bepaling in art. 52 ,dat in de steden daar dc voorsz. Walsche Kercken zijn, alle maenden sommighe Dienaren ende ouderlingen van beyde zydens vergaderen zullen om goede aandacht ende correspondentie met malcanderen te houden, ende zoveel moghelijk is na geleghenheyt des noodts met rade malcanderen by te staen".

\section{Die verskeidenheid.}

Die noodsaaklikheid van ekumeniese kerkverband is dus na wat in die voorafgaande gesê is vanselfsprekend, en dit is dus ook vanselfsprekend dat terwyl daar bv. ook nic-blanke Gereformeerde gemeentes is, hulle ook in een Algemene Sinode ingeskakel moet word. Dit volg uit die beginsel dat 
dit wenslik is dat al die kerke van dieselfde belydenis in die verskillende lande en onder die verskillende volke in een ekumeniese sinodeverband moet wees. Dit behoort nie 'n probleem te wees nie.

Daarmee is egter nog nie die vraag afdoende beantwoord waarom daar aparte gemeentes onder die nie-blankes in dieselfde land moet wees nie en waarom hierdie gemeentes in aparte meerdere vergaderings byeenkom. Om hierop te antwoord en om die betekenis van die verskeidenheid aan te dui sal ons nader op die verskeidenheidsaspek moet ingaan.

Ons spreek van verskeidenheid in die kerk en nie van eiesoortigheid nie, omdat eiesoortigheid daarop dui dat ons te doen het met wesenlik andersoortigheid tussen verskillende volke of rasse. So iets ken die Skrif nie. Ons vermy ook liewer die woord "pluriformiteit" van die kerk omdat veral deur die betekenis wat Kuyper daaraan geheg het, dat daar nl. pluriformiteit van kerke kan wees wat self in belydenis met mekaar kan verskil, die woord in 'n slegte reuk te staan gekom het.

Om die saak in die regte perspektief te sien, kom ons weer terug op die teologiese fundering. Terwyl daar verskeidenheid in die Drie-eenheid is, het God ook 'n verskeidenheid gelê in die mensheid wat Hy na sy beeld geskape het. Daar sou 'n verskeidenheid van volke in die eenheid van die mensheid gewees het indien die sonde nie ingetree het nie, want "God het uit een bloed al die nasies van die mensdom gemaak om oor die hele aarde te woon, terwyl Hy vooraf bepaalde tye en die grense van hulle woonplek vasgestel het sodat hulle die Here mag soek" (Hand. 1:26, 27). Daarom is daar in die nuwe mensheid, wat die liggaam van Christus is, 'n ryke verskeidenheid. Dit volg ook uit die aard van ' $n$ organisme soos wat die liggaam van Christus is. Dit is 'n liggaam, sê Paulus, wat goed „saamgevoeg en saamverbonde is deur die ondersteuning wat elke lid gee volgens die werking van elke afsonderlike deel in sy mate" (Ef. $4: 16$ ). Daar is verskeidenheid in die liggaam van Christus en nie 'n doodse enersheid nie, want „as die hele liggaam oog was, waar sou die gehoor wees? As dit geheel en al oor was, waar sou die reuk wees?... As almal een lid was, waar sou die liggaam wees?" (1 Kor. $12: 17,19)$.

In hierdie verband is die eskatologiese verskeidenheid in die nuwe Jerusalem waarin al die nasies hulle eer en heerlik- 
neid sal inbring (Openb. 21 : 26) van groot betekenis. Van daardie verskeidenheid moet daar reeds nou 'n weerkaatsing, 'n voorafskaduwing in die kerk onder die volke gesien word.

Benewens hierdie teologiese fundering is daar nog ander baie belangrike faktore wat meebring dat verskeidenheid vanselfsprekend in die kerklike lewe moet volg. Daar moet in die eerste plek rekening gehou word met die feit dat elke volk sy eie probleme, geskiedenis en kultuur het. In die besondere situasie van elke volk en onder die besondere omstandighede van elke volk moet die koninkryk van God asook die uiteindelike bestemming van die gelowiges as individue maar ook as verteenwoordigers van die betrokke volke in die besondere verhoudinge en probleme, en teenoor die besondere heidendom en ongeloof, geopenbaar word, en in hierdie besondere omgewing van elke volk moet die kerk groei tot die volheid in Christus, tot die eenheid van die geloof en die kennis van die Seun van God (Ef. $4: 13$ ).

As die „Evangelie onder telkens weer anders geaarde volkeren gestalte krijgt", sê dr. H. Berkhof, "geschiedt dit steeds weer in een strijd tussen het Evangelie, dat "niet is naar de mens" (Gal. 1 : 11) en het natuurlike denken dezer verschillende cultuurgroepen. Het Evangelie was voor de Joden een ergernis en voor de Grieken een dwaasheid. Elke denkvorm moet eerst door de openbaring worden gekruisigd om op te kunnen staan tot dienstbaarheid aan het heil. Waar dat geschiedt en in zoverre dat geschiedt wordt de traditie der kerk met een nieuw verstaan van het Evangelie verrijkt" (De Katholiciteit der kerk, p. 78, 79).

Die Here het self ook met Pinkster aangetoon dat daar in die kerk gereken moet word met die bestaan van aparte tale en dus ook aparte nasies, want toe het almal wat met die geleentheid byeen was die verkondiging van die groot dade van God elkeen in sy eie taal gehoor. Stauffer sê dienaangaande die volgende: „Daar waar dieselfde Logos onder alle volke in dieselfde taal verkondig word, en daar waar in verskillende tale verskillende logoi verkondig word, daar is die Gees nie. Waar egter dieselfde Logos in baie tale verkondig word, waar die Boodskap van die een Naam onder die hemel aan elke volk in sy eie taal kom, daar is die Gees an die werk" (E. Stauffer: Die Theologie des N.T., Gütersloh, 1948, p. 174). Dit is dan ook vanselfsprekend dat die gemeente die Woord in sy eie taal moet hoor; alleen hierom is daar al 
aparte gemeentes nodig, anders is die bediening van die Woord kragteloos. Dit moet so wees selfs waar lede van een volk onder 'n ander volk woon met wie hulle nie kan of wil assimileer nie.

Verskeidenheid in die kerk volg ook daaruit dat dit in die Skrif nie bloot gaan om die redding van individue nie, maar om die mensheid en in die mensheid om die volk Israel en alle nasies wat in hulle gelowiges gered word (Luk. $22: 14$, Rom. 9-11, Jes. 66 : 12, Dan. $12: 1$ ). Die universaliteit van die kerk is nie 'n universaliteit van geatomiseerde individue nie, maar dit is 'n universaliteit wat alle volke as volke insluit, die ware volk in elke volk wat uit die gelowiges in elke volk bestaan. ' $n$ Verskeidenheid in die kerk van die Here volgens die verskeidenheid van volke. Daarom sê Stauffer heeltemal tereg dat die kerk nòg volkskerk, nòg wêreldkerk kan wees, maar volkerekerk. Met Pinkster word die uitmekaar verskeurde volkerewêreld in 'n nuwe eenheid versamel, die eenheid van die volkerekerk (E. Stauffer, a.w., p. 174). Ons kan hier byvoeg dat ons ook nie spreek van 'n rassekerk nie, waarin die verdeling volgens die verskillende rasse gaan. So ' $n$ begrip ken die Skrif nie. Dit sou daarop neerkom dat die huidskleur bepalend is in die kerk van die Here. Ons spreek van 'n volkerekerk, waarvan die verskeidenheid en die universaliteit veral daarin geopenbaar word dat dit 'n kerk is onder alle volke.

Uit die bestaan van aparte gemeentes volg vanself dat daar ook tot op nasionale vlak aparte institutêre verband moet wees. Ook die aardse bande „van tot een natie behooren", sê Kuyper, oefen oorwegend invloed uit in die kerkverband. (A. Kuyper: Uit het Woord, VI, Amsterdam, 1886, p. 47). Dit regverdig egter nog nie 'n kerkverband net tot by die nasionale grense nie. Dan sou daar van mekaar onafhanklike kerke onder die verskillende volke wees. Dan sou ons verskeidenhede kry, maar geen eenheid in die verskeidenheid nie, nie 'n eenheid van verskeidenheid nie. Die universaliteit van die kerk onder die volke, die verskeidenheid en eenheid moet geopenbaar word in 'n volkerekerk.

Dit word vandag algemeen in die Protestantse sending erken dat daar 'n verskeidenheid in die kerke onder die nieblankes moet wees. Die kerke moet soos gesê word verinheems word. Ook in Afrika pleit nie-blanke kerklike leiers daarvoor dat die kerk 'n inheemse karakter moet dra. Soos die 
kerke nou is word hulle aangevoel as vreemde Westerse instellings. Hieraan wil hierdie mense nou verandering bring. In die reël volg die vreemdheid van die kerk egter hoofsaaklik uit die feit dat afgewyk is van die suiwerheid en eenvoudigheid van die Skrifwaarhede, en die gevaar is dat indien te veel by die volksaard en denke aangepas word, nog verder in hierdie verkeerde rigting gegaan sal word. 'n Verdere gevaar is dat 'n te groot nadruk op verskeidenheid die verdere deurwerking van die gedagte van onafhanklike kerke in die hand kan werk.

Desnieteenstaande moet vanweë die verskillende hierbo genoemde faktore en omstandighede die verskeidenheid in die liggaam van Christus ook in die kerk van die Here onder die verskillende volke geopenbaar word. Daar kan in 'n sekere mate variasie in belydenis, kerkregering en erediens wees, maar 'n essensiële vereiste is dat daar ' $n$ wesenlike en fundamentele eenheid in Skrifgebondenheid moet wees, en wat die Gereformeerde kerkverband betref, moet daar 'n oorname wees van die waarhede wat die Geref. Kerke in die loop van die geskiedenis in leer, diens en tug uit die Skrif geput het, uitdrukking gebring kan word. „Schakeering in uiting der lippen (belijdenis) en uiting der aanbidding (culte) is mogelijk. Voor vele dingen zijn geen bepaalde voorschriften in het Woord; daarom is bij behoud der beginselen en de daaruit getrokken hoofdlijnen, rijkdom van schakeering naar tijd, toestand, volkskarakter enz. gewenscht" (A. Kuyper: Acta Zending-Congres 1890, p. 9).

Ook Calvyn het 'n ope oog gehad vir die verskeidenheidsgedagte in die kerk. Insake die erediens bv. sê hy dat daar in alles orde en reel moet wees, maar, terwyl God wat die uitwendige orde en seremonies betref, nie 'n besondere voorskrif wou gee van wat ons daarin moet volg nie (omdat $\mathrm{Hy}$ deursien het dat dit afhang van die geleentheid van die tye, en ook geoordeel het dat dieselfde vorme nie in alle tye pas nie), so moet ons hier die toevlug neem tot die deur Hom gegewe algemene reëls, en daarvolgens al die instellinge skik, wat die behoefte van die kerk tot die bewaring van die orde en eerbaarheid sal vorder. Eindelik, terwyl Hy dus daarvan niks uitdrukliks geleer het nie, omdat dit vir die saligheid nie nodig is nie en ooreenkomstig die sedes van elke volk en elke tyd onderskeidelik toegepas moet word tot opbou van die kerk, so mag mens sowel die gebruiklike verander en 
afskaf as nuwes instel, soos die nut van die kerk vereis" (J. Calvyn, Institusie, IV, 10,30).

\section{Die kerkverband in werking}

Uit die voorafgaande blyk dat sowel uit die cenheid as die verskeidenheid en universaliteit van die kerk volg (a) dat daar aparte gemeentes onder die verskillende volke moet wees; (b) dat die kerkverband van die gemeentes moet deurgaan tot op nasionale vlak; (c) dat dit egter nie hier kan eindig nie, maar oor die volksgrense moet gaan, daar moet 'n ekumeniese kerkverband wees.

Enige ander weg as die suiwer Skriftuurlike lei tot verkragting van een of meer van die drie aspekte van universaliteit, verskeidenheid en eenheid. Waar bv. 'n veelrassige kerk die reèl is word geweld aangedoen aan die verskeidenheid maar ook aan die eenheid en universaliteit van die kerk, en van mekaar onafhanklike kerke onder verskillende volke kom daarop neer dat die eenheid nie tot sy reg kom nie. Die Geref. Ekumeniese Sinode 1963 het dan ook heeltemal tereg verklaar dat wanneer daar 'n organisatoriese verband is tussen die gemeentes onder die verskillende volke, die een kerk van Christus in sy universaliteit, sy eenheid en sy pluriformiteit in toenemende mate geopenbaar sal word.

Die aanbevelings van die deputate $a d$ hoc aan die algemene sinodes van die Geref. Kerk in S.A. (1958, 1961 en 1964) en die besluite van die Sinodes van 1961 en 1964 wat daarop neerkom dat die verskillende taal- en volksgroepe plaaslik hulle eie kerke institueer asook hulle eie kerkverband tot op nasionale vlak; dat die kerkverband oor die nasionale grense noodsaaklik is om die geestelike eenheid tot openbaring te bring en dat die onderlinge verband voorts gehandhaaf moet word deur deputate van gemeentes en meerdere vergaderings, is, soos uit die voorafgaande duidelik is, heeltemal in ooreenstemming met die Skrif en belydenis asook met die tradisionele Geref. opvatting en praktyk (vgl. o.a. die reeds genoemde besluite van die Algemene Sinode 1955 en van die Geref. Ekumeniese Sinode 1963 asook die Dordtse Kerkordes van 1578 en 1618-1619). Die handhawing van die onderlinge verband deur deputate sal, soos die Sinode (1964) verklaar het, meebring dat die gesamentlike sinode nie te dikwels en gereeld hoef te vergader nie. 
Die Geref. kerkverband ooreenkomstig etniese verdelings is reeds in Suid-Afrika in werking en die eerste "Algemene Sinode van Geref. Kerke in Suidelike Afrika" het op 28-30 Junie op Potchefstroom vergader. Mag dit die voorloper wees van 'n Geref. Ekumeniese Sinode warop al die Geref. kerke oor die hele wêreld, wat fundamenteel een is in belydenis, kerkorde en liturgie verteenwoordig word.

P.U. vir C.H.O.

H. du Plessis. 